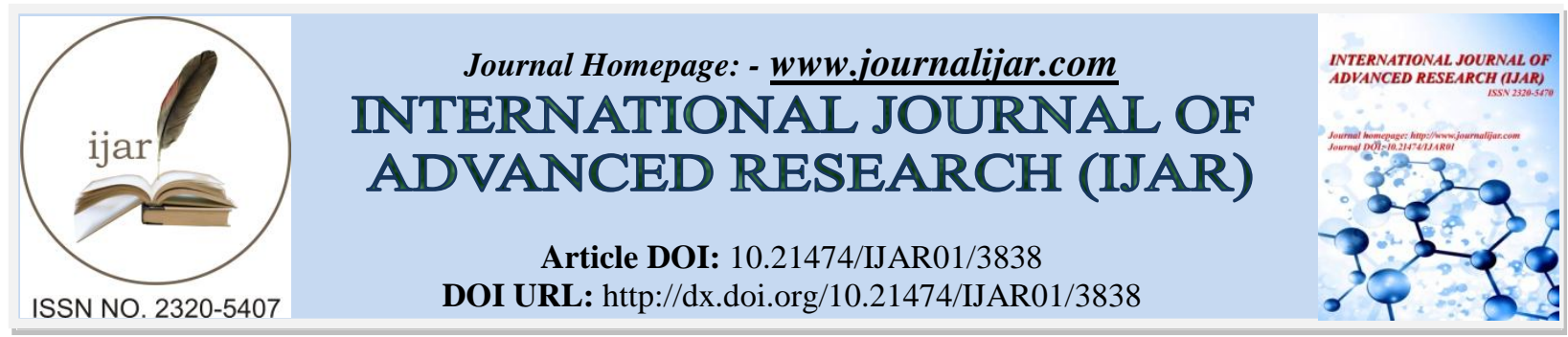

RESEARCH ARTICLE

\title{
INSTRUMENTS AND INSTITUTIONAL MECHANISMS FOR INCOME TAX ENFORCEMENT IN NIGERIA
}

*Dr. Kareem Adedokun

Senior lecturer at the Department of Business and Private Law, College of Law, Kwara State University, Malete.

\section{Manuscript Info}

Manuscript History

Received: 01 February 2017

Final Accepted: 05 March 2017

Published: April 2017

\begin{abstract}
A thorough understanding of legal and institutional framework for tax enforcement and their application to tax practice is a sine qua non for effective tax administration. In the last couple of years, events have revealed that tax administrators are exhibiting ignorance of the explicit procedures governing enforcement of tax. This is manifest in the application of tax enforcement method that is alien to relevant tax laws by revenue authority. To put the principles and procedures of income tax enforcement in their proper perspectives, this paper, apart from giving conceptual clarification of terms related to enforcement, examines sequentially various tax enforcement instruments and institutional mechanisms regulating them with the ultimate view of pointing out critically legal deficiencies in them. The paper finds that enforcement by distress is not the same with sealing up of business premises but tax administrators are employing the latter instead of the former .It is equally discovered that method of post-judgment execution provide $\mathrm{d}$ for by Companies Income Tax Act is alien to Nigerian civil jurisprudence. Finally, the paper finds that buck passing between Independent National Electoral Commission and courts on enforcement by tax clearance certificate is not in tandem with the relevant tax law. Consequently, the paper suggests urgent amendment of the relevant provisions of the tax law identified in this paper.
\end{abstract}

Copy Right, IJAR, 2017,. All rights reserved.

\section{Introduction:-}

The rate of tax compliance is generally low in Nigeria ${ }^{\mathbf{1}}$. As a matter of fact, tax payers are exhibiting indifferent attitudes and apathy to tax payment ${ }^{2}$. The reasons for the pervasive low tax compliance are multifarious.It is believed that Nigerian income tax systems are only meant for funding government projects and expenditures rather than being instruments for socio-economic improvements ${ }^{3}$. Other reasons are lack of logistics, political interference,

$1 \quad$ FIRS Raids Tax Defaulters, In Daily Trust, Wednesday, September 12010 , p7

2 Nigerian Tax Reform in 2003 and Beyond, Report of the Study Group on Nigerian Tax System 2003 , p 270 $3 \quad$ Ibid 
slow judicial process, bribery and corruption; unskilled cum poorly motivated staff, and ignorance to mention but few ${ }^{4}$.

Therefore in order to boost high revenue yield, tax requires modicum of force to compel obedience to it. The process is referred to as enforcement procedure. It is a fundamental imperative of a good tax system because it constitutes a benchmark for measuring the standard for effective tax administration. The income tax laws ${ }^{5}$ create various mechanisms for enforcement of income tax. This paper takes a critical look at the legal framework governing enforcement of income tax in Nigeria and the challenges which they pose. It equally discusses briefly the administrative mechanisms for income tax since taxation is generally statutory. The paper highlights principally the components of the income tax enforcement instruments with the aim of fizzling out their legal deficiencies as well as their misapplication in practice.

\section{Conceptual Clarification Of Key Terms:-}

The legal framework and institutional mechanisms for tax enforcement are the thrust of this paper and as such understanding them for tax purposes is essential to the discourse. One of the cardinal imperatives of taxation is certainty. This explains why the scope of the chargeable tax should be clear both in form and content. The logical implication of this is that tax being a product of statute, liability to it must be ascertainable pursuant to taxing statute. Tax liability carries along enforceability either by civil remedy or punitive measures. In other words as tax principles are outlined by law, so also the legal instruments for enforcement must be prescribed by a written law. Their scope and procedures are borne out of the content of tax law that defines them. For instance, Section 86(1), Companies' Income Tax Act (CITA), Section 104, Personal Income Tax Act and Section 33 (1), Federal Inland Revenue Service (Establishment) Act that provide for power to levy distress, lay out requisite conditions for its application and outline its procedures. Not only this, Section 34 (1), FIRS Act that makes litigation an enforcement instrument equally gives directives of how it can be used within the conventional rules and procedures of the court. $^{6}$ Thus, any derailment from the limit set by these legal prescriptions may amount to illegality.

The income tax laws equally make provision for administrative instrumentalities through which tax objectives of government are realized. They encapsulate human resources (tax officers) and facilities (tools) for the goals of government from tax to be achieved. In other words, human resources and facilities constitute two essential components of administrative mechanisms to enforce income tax. Tax is a dynamic economic phenomenon and the instrumentalities for its enforcement cannot afford to be retrogressive. This being the case, while the substantive law of taxation is being amended or improved to align with international best practices, the organizational structure of its administrative agencies must equally be reinvigorated to accommodate the progressive tendencies of the law. For the human element, guidelines are made available for tax administrators to improve their efficiency in tax administration. This will enhance the understanding of their roles in achieving the overall objectives for which their department or agency is established.

Be that as it may, the examination of the legal frameworks for income tax enforcement in Nigeria in this paper is with the view to analyze them within the context of ultimately finding solutions to the problems militating against their effectiveness.

\section{Enforcement Instruments:-}

The Companies' Income Tax Act prescribes various legal instruments to enforce tax recovery. They are distress; legal proceedings (this constitutes civil litigation and criminal prosecution for tax delinquencies); search and seizure as well as tax clearance certificate system. The discourse below analyzes these instruments in order to stake out their deficiencies and to confirm whether their application in practice conforms to statutory provisions of the law creating them.

\footnotetext{
$4 \quad$ Ibid p.101

5 Companies' Income Tax Act,CAP C21, Laws of Federation of Nigeria (LFN), 2004: Personal Income Tax Act, $\quad$ CAP P8 (LFN) 2004; Petroleum Profits Tax Act, CAP C1, LFN, 2004
} 


\section{Recovery of Tax by Distress:-}

Distress is the seizure of personal property of the tax defaulter to enforce payment of income taxes to be followed by its public sale if the taxes are not voluntarily paid ${ }^{7}$. By this, the personal goods and chattels of the tax defaulter or that of the third party in his safe keeping is impounded and taken out of his possession into the custody of the relevant tax authority to procure a satisfaction for non-payment of tax or arrears of tax due from the tax defaulter.

By virtue of Section 86(1) CITA, 2004 and Section 33 (1) FIRS (Establishment) Act 2007, the Federal Inland Revenue Service is empowered to levy distress on a tax defaulter. A community reading of the sections shows clearly that the exercise of power to distrain by the FIRS is discretionary and optional. The authority has the option of enforcing income tax by means other than distress. In other words, if distress is chosen as an instrument to enforce income tax on a tax payer, other instruments become otiose for the same purpose. However, the tax authority must exercise its discretion judiciously by ensuring that all the requisite conditions and procedures guiding distress are fulfilled and complied with before distraining the tax defaulters' properties.

Distress as an instrument to enforce tax is regulated by rules and procedures. The rules are prescribed by the law and are meant to be strictly followed to avoid encroachment on the fundamental human rights of the tax payers. Suffice to point out that there are requisite conditions to the exercise of the power of distraint for non-payment of tax. First, the power becomes exercisable only when assessment raised against the tax payer becomes final and conclusive. That is when the tax payable has been decisively determined and no valid objection or appeal has been lodged against the assessment within the time prescribed by the law ${ }^{\mathbf{1 0}}$, and no further notice has been given of a further appeal against a decision of the Appeal Commissioner or a judge ${ }^{\mathbf{1 1}}$.

The second requisite condition for levying of distress is a prior demand, which is essentially compulsory. Where an assessment is made without a demand for a return of income, such an assessment is made without jurisdiction and would therefore be ultra vires, null and void ${ }^{\mathbf{2}}$. The demand note must be served on the tax payer. Besides, a reasonable time limit within which the tax payer is expected to comply with the demand note must be specified thereon and the time between demand and distraint must have lapsed ${ }^{13}$. In other words, the request for a demand is a condition precedent. The waiting for the time allowed in the demand notice to pass is also a condition precedent. Both conditions are intended to protect a person by affording him an opportunity of stating his income and other relevant matters. An assessment which does not fulfill either of those conditions is made without jurisdiction and it is null and void ${ }^{14}$.

It is pertinent to observe that though section 55 CITA 2004 mandates every company to file a return at least once a year without notice or demand from the Revenue Board, the provision is only applicable to self-assessment filers. Never the less, the writer of this paper is not oblivious of the fact that Companies' Income Tax (Amendment) Act 2007 deleted Sections 55 of the principal Act (i.e. CITA). Notwithstanding, it is his humble view that CITA (Amendment) Act 2007 is Otiose. It is observed that CITA (Amendment) Act 2007purportedly amended CITA, CAP 60 LFN, 1990 which has been re-arranged and enlarged by incorporating some legislation between 1990 to2004 and consequently codified it as CAP C21, LFN 2004. It is noteworthy that Section 55 CITA CAP 60, LFN 1990 provides for procedure before Appeal Commissioners. The Section is re-numbered as Section 73 of CITA CAP C21, LFN, 2004. So if the National Assembly in 2007 would delete the section of CITA regarding procedure before Appeal Commissioner, it should be Section 73 of CITA 2004 and not section 55 of CITA 1990. ${ }^{15}$

10 Section 66, Personal Income Tax Act, CAP P8, Laws of Federation of Nigeria (LFN), 2004

11 Seyi Ojo- Fundamental Principles of Nigerian Tax, Sagribra Tax Publications, Lagos, 2003, P23

12 Joseph Rezcallar\& Sons Ltd v FBIR (1962) 1 All NLR, 1

$13 \quad$ Gibbs $v$ Stead (1828) B \& C 528

$14 \quad$ Joseph Rezcallar\& Sons Ltd v FBIR (Supra)

15 Section 14, Companies' Income Tax (Amendment) Act 2007 deleted section 55 of CITA, 1990. However in the Laws of Federation of Nigeria updated to $31^{\text {st }}$ December, 2010 pursuant to the Revised Edition (Laws of Federation of Nigeria) Act, 2004, the editor wrote in section 56 thus: "Please note that although section 14 of the Act No 11 of 2007 instructs section $41 A$ to be deleted, it is suggested that it is intended to delete section 56". The editorial note/suggestion cannot alter provision of the law. It has to go through the same process by which 2007 amendment Act was made. 
It is imperative to state that the legislative error as pointed out here is the effect of unnecessary duplication of legislation which Nigeria is found of. ${ }^{\mathbf{1 6}}$ Section 55 CITA 2004 remains intact and in the humble view of this paper, it conflicts with section 86(1) CITA 2004 and section 33 (1) FIRS Act 2007 which makes demand notice mandatory before assessment.

For the purpose of levying distress, a tax collector must obtain a warrant of distress. The warrant is a writ authorizing the revenue officer to make a distress ${ }^{17}$. It is an authority issued to a collector of taxes, empowering him to make distress and sale of goods or land in default of payment ${ }^{18}$. The law provides that the warrant must be issued and signed by the chairman of the Federal Inland Revenue Service ${ }^{\mathbf{1 9}}$. Although this is the position of law, it is observed to be a flagrant usurpation of the judicial power of the court; as such it is at variance with constitutionalism. Going by the definition of the warrant of distress above stated, the warrant, has the same status with warrant of arrest under criminal proceedings or at best being a writ, it is ejusdem generis with writ of fiery facie, otherwise known as writ of execution and as such it has to be a judicial order authorizing or directing a revenue officer to perform a specified act. That is levying distress. In this regard, it is only a judicial officer and not an executive or administrative officer that is qualified to issue it. We are strengthened in this proposition by section 36 (2) FIRS (Establishment) Act which provides that a judicial officer must issue the warrant of search and seizure. This conforms to the principle of separation of powers recognized by the Constitution of Nigeria, 1999. Anything contrary may result to executive encroachment on judicial powers. Besides, authorizing the chairman of Federal Inland Revenue Service to sign or issue the warrant portends danger as the power may be abused for political advantage especially in Nigeria where fiscal mechanism and political aspect are not treated as independent variables $^{20}$.

If the warrant is laid before a judicial officer in chambers before it is issued, it will create an opportunity for it to be preceded by a judicial inquiry that will satisfy the judge that the requirements for its issue have been met. Otherwise, it will constitute a derogation of the tax payer's right to own property. Nevertheless, the warrant must set out the full identity of the collector and the fact that he is authorized to exercise the functions of a tax collector ${ }^{21}$. Then, the tax collector may break open any building or place in the day time for the purpose of levying distress, first on the tax payer's goods or other chattels, bonds or other securities ${ }^{22}$. The distrainable goods may be tangible or intangible goods but not perishable goods $\mathbf{2 3}^{\mathbf{2 3}}$. This is because goods of a perishable nature cannot be restored in the same state as that in which they were taken ${ }^{24}$. In this respect, tax is charged on the person and only goods belonging to the person so charged can be seized and taken. Second, the tax collector may distrain upon any land, premises, or place in respect of which the tax payer is the owner; thereby empowering him to distrain on any goods found on the premises, including those of third parties ${ }^{25}$.

One advantage of the procedure of distraint is the idea of making it open and public. This brings social stigma and disfigurement on the tax defaulter and may serve as deterrent to others. However, lack of courage, ignorance and apathy on the part of tax collectors has not made this enforcement procedure yield a positive result. In the last couple of years, events have revealed that tax administrators are exhibiting ignorance of the explicit procedures governing distress. They grope in darkness in a so manifestly obvious manner that when they intend to distrain, they embark on sealing-up of business premises of companies, which method is alien to Nigerian income tax laws ${ }^{26}$. This is clear

16

17

18

19

20

of

21

22

23

For instance substantial provisions of EFCC Act and ICPC Act are already provided for in PenalCode and Criminal Code respectively.

Section 86(2), CITA, 2004; see also section 33 (2), FIRS (Establishment) Act, 2007

Garner B.A. op.cit p1616

Fourth Schedule, CITA, 2004; Fourth Schedule, FIRS (Establishment) Act 2007

Ayoade J.A- The Changing Structure of Nigeria Federalism; In Elaigwu J. \&Akindele R (ed) Foundations Nigeria Federalism, National Council on Inter-Government Relations (N.I.R) Abuja, Federal Capital

territory (FCT), Nigeria, Vol.2 1996, p56

Section 33 (2), FIRS (Establishment) Act, 2007

Ibid, Section 33 (3)

Morley v Pincombe (1948) 2 Ex. Ch. 101

Simon's Income Tax, $2^{\text {nd }}$ edition Vol. 1, Butterworths 1952, p.322

Jusen v Dixon (1813) $1 \mathrm{~m} \&$ s 601, Macgregory v Clamp \& Sons (1914) 1,K.B 288

A.M shittu v NACB Ltd \& 2ors (2001) 10 NWLR (Pt 721) p.298 
indication of lack of periodic training of tax officials to update their knowledge in other to enhance their performances.

\section{Enforcement of Tax by Legal Proceeding:-}

The term legal proceeding means proceeding before any court, tribunal or person having the power by law to hear, receive and examine evidence on oath ${ }^{27}$. It may be civil or criminal. This sub-head discusses civil proceeding. Under the income tax laws, government of the federation or the relevant tax authority are empowered to sue for recovery of income tax in a court of competent jurisdiction with full costs of action from the person charged therewith as a debt due to $\mathrm{it}^{28}$. In this regard, a court of competent jurisdiction includes High Courts (State or Federal) and Magistrate's court provided the amount claimed in any action does not exceed the monetary limit of the jurisdiction of the Magistrate concerned with respect to action for $\mathrm{debt}^{29}$.

The power of the High Court to recover unpaid tax may be either in its original jurisdiction, supervisory jurisdiction or appellate jurisdiction. Original jurisdiction is the power of the High Court to hear and decide a matter as a court of first instance before any other court can review the matter ${ }^{30}$. Supervisory jurisdiction arises when upon leave of the court the proceedings of any inferior court or tribunals (magistrate court or body of appeal commissioner) is brought before it for the purpose of being quashed for either ultra vires (excess of power); illegality (error of law); irrationality (unreasonableness) and procedural impropriety (violation of rules of natural justice) ${ }^{31}$ This is what is technically referred to as judicial review. Appellate jurisdiction of the high court is the power it has to review and revise a lower court's decision by way of an appeal brought before it.

The jurisdiction of the state high court becomes exercisable on tax matters only if the revenue to be recovered is that accruable to the state and the state Internal Revenue or state Government is a party. Companies' income tax is recoverable at the Federal High Court. In other words, if the tax recoverable is that of the state, regardless of whether the defendant tax defaulter is a Federal Government's agency; the state high court will have jurisdiction. Although the supreme court in the case of NEPA $V$ EDEGBERO ${ }^{32}$ decided that a state high court will no longer have jurisdiction on matters in which the Federal Government or any of its agencies is a party notwithstanding the nature of the claim. A situation whereby a state high court is to recover a state's revenue from the Federal Government or any of its agencies is an exception to that apex court decision ${ }^{33}$. This is particularly so that Section 251 (1) (a) of the 1999 Constitution vests exclusive original jurisdiction on Federal High Court only when the revenue to be collected is that of the Federal Government. Besides, Section 251 of the Constitution does not confer jurisdiction on parties but on subject matter or nature of the suit ${ }^{34}$. Be that as it may, the procedure for instituting civil proceeding to recover tax is as prescribed by the various civil procedure rules of the courts. One common criticism of Nigerian courts is the delay in proceedings. In proffering solution to this problem various States have evolved a new High Court Civil Procedures Rules introducing front-loading system. However one noticeable flaw in the new rules, particularly in Kaduna State, is the clumsy nature of its summary judgment procedure which would have assisted quick disposal of tax cases to enhance revenue generation. A critical look at Order 11 of the High Court Civil Procedure Rules of Kaduna State, 2007, reveals that it is slower than the undefended list procedures in the old rules that it claims to improve upon in terms of time consumption and complexity of the procedures

$27 \quad$ Garner B.A- Black's Law Dictionary, op.cit p915

28 Section 34 (1), FIRS (Establishment) Act, 2007, Section 87( 1), CITA, 2004: Section 78 (1), PITA, 2004

$29 \quad$ Section 87 (2), CITA, 2004

$30 \quad$ Sections 251, $257 \& 272$ (1) \& (2), CFRN, 1999.

31 Abdulrazaq M.T - Nigerian Revenue Law, MaltHouse Law Books, Lagos, 2005, p19, see also Order 37 Kaduna State High Court (Civil Procedure) Rules 2007, see also Section 272 (2) CFRN, 1999, and the cases of Civil Services Commission Imo State \& lor v Godwin Onyema Anuforom(2007) ALL FWLR (Pt 396) 155 @ 172, Rayyawu Mohammed V KSBIR \& 20rs unreported suit N0: KDH/Z/02/2007, per B.F Isah J; $R$ VIRC (1982) Ac 617.

$32 \quad$ (2002) 18 NWLR (Pt 798) p79.

33 Adedokun K.A. The Rule in NEPA V EDEGBERO.A case of Absolute Rule? An article published in Ahmadu Bello University Zaria, Journal of Private and Corporative Law (JPCL) vol. 2 \& 3, 2007 -2009 Pp191-196. 
involved. It is pertinent to emphasize that tax may be recovered by summary procedure in the High Court where the relevant tax authority believes there is no defence to the claim from the tax defaulter. The procedure is a truncated form of ordinary civil hearing designed to ensure quick dispensation of justice but not at the expense of fair hearing. Also tax can be recovered through a full trial begun by writ of summons wherein evidence is lead and judgment delivered. However, the summary procedure under the Kaduna High Court Rules is cumbersome and can slow down dispensation of justice rather than quicken it.

Never the less, where the Federal Inland Revenue Service or any other relevant tax authority has obtained judgment against a company or tax payer, execution of such judgment against the judgment debtor (tax defaulter) follows. In spite of this trite position of the law, Section 88 (2) CITA, 2004 provides that post-judgment default by tax payer can be addressed by issuance of a bench warrant on the director of the company. This provision is a misconception of the law. In fact, it is an aberration from the Nigerian civil procedure jurisprudence. In the first instance, the judgment envisaged by the provision is a monetary judgment obtained through civil proceedings. As such, the issuance of bench warrant does not arise. Bench warrant is issued by the judge to a law enforcement officer especially for the arrest of a person who has been held in contempt; has been indicted; has disobeyed a subpoena or has failed to appear for a hearing or trial ${ }^{35}$.

Again, six months grace after the judgment is obtained and the judgment sum remains unpaid as provided in the same section, is not desirable; except if appeal is lodged against the said judgment and an application for stay of execution accompanies it; otherwise the six months period, in the humble view of this writer is tantamount to indifferent attitude towards revenue accretion to Government treasury.

Rather, the next step after obtaining judgment by the FIRS is the execution of the judgment. This is the enforcement of that judgment by giving effect to it except in declaratory judgment or when the judgment is voluntarily complied with $^{\mathbf{3 6}}$. By virtue of Order IV Rule (2) Judgments (Enforcement) Rules, except by leave of the court by way of motion ex-parte, execution cannot be levied on the judgment debtor (tax defaulter) until after the expiration of three days after the judgment is entered.

Judgment obtained by the Revenue Authority against a company or an individual can be enforced either by writ of fieri facie (writ of fifa) or garnishee proceeding. The writ of fifa is the most commonly used means of execution. Its essence is that the judgment sum is realized by the seizure and then sale of judgment debtor's properties and chattels. This is different from levying distress. The main difference is that distress is an enforcement measure on its own, which if the tax authority chooses it, litigation serves no useful purpose any longer. Execution of judgment by writ of fifa is adjunct or incidental to litigation after obtaining judgment against the tax payer.

Garnishee proceeding is a post-judgment proceeding where the judgment creditor (FIRS) may attach or garnishee debts which the judgment debtor (tax defaulter) owes in satisfaction of the judgment sum. The garnishee is usually a third party such as bank or financial institutions in whose custody the judgment debtor is suspected to have enough fund to settle the judgment sum.

\section{Monetary Penalties and Criminal Prosecution:-}

The income tax laws ${ }^{37}$ make adequate provisions for monetary penalties or terms of imprisonment or both for certain tax delinquencies pursuant to criminal prosecution. Tax delinquency is a technical term for failure or omission to pay tax when due with criminal intention. Such delinquencies prescribed by the law are; failure to deduct tax; nonpayment of income tax; making incorrect returns; false statement and returns; obstructing a tax collector, obstructing a tax officer to conduct search and impersonating tax officials ${ }^{\mathbf{3 8}}$.

$35 \quad$ Garner B.A-Black's Law Dictionary, op.cit p162

36 Nwadialo F- Civil Procedure in Nigeria, M.J Professional Publishers Limited, Lagos, 1990, p765

$37 \quad$ PITA, CITA\& FIRS Act 2007

38 See Sections 74, 76,94,95,96 \& 97, PITA, 2004 and Sections 40-46 Federal Inland Revenue

(Establishment) Act, 2007. For detail discussion of all the tax delinquencies see Abdulrazaq M.T Nigerian Tax Offences and Penalties, Tosco Press Ilorin, 1993 P85; Graham Balter - Tax fraud and

Evasion $5^{\text {th }}$ ed, Werren, Graham \& Lamont Inc. U.S.A, 1982. Adedokun K.A - Enforcement and Recovery of Income Tax in Nigeria (Law, Practice, and Procedures), Corporate Transactions Ltd,

Lagos, 2010, Pp51- 71 
It is instructive to state that payment of penalties for default in tax matters is quite different from criminal prosecution which upon conviction may earn term of imprisonment. The main difference between the two is that while penalties are imposed privately and subject to the general confidentiality that surrounds a person's tax affairs; criminal prosecution are conducted in open court ${ }^{39}$. A criminal prosecution does not exclude penalties and does not relieve a person from liability to payment of any tax for which he is or may become liable ${ }^{\mathbf{4 0}}$. In other words, criminal prosecution and civil action for recovery of tax due can go on simultaneously

The tax delinquencies are offences of either commission or omission. The general effect of them is to forbid tax avoidance and evasion but to enjoin performance of civic obligations of payment of tax. The actus reus is the physical aspect of the tax offences. It is the definitional element of each of the tax offences which constitute the ingredients which must be proved beyond reasonable doubt before any tax accused may be convicted. Failure on the part of the prosecuting tax authority to establish each of the ingredients of the offences would be resolved in favor of the tax accused.

However, the mere commission of any of the tax offences is not enough to ground term of imprisonment or fine. The mental element required for those offences must equally be proved beyond reasonable doubt. The prosecuting tax authority must establish that there is a criminal intent, guilty knowledge and willfulness on the part of the tax accused. This is what is technically referred to as mens rea; a guilty mind. The general spirit of the tax offences is that they are not offences of strict liability but of intentional liability.

The income tax laws that create those offences provide that mens rea is an essential ingredient of them. This is evident from the words such as willfully, lawful justification, reasonable excuse, knowingly, unlawfully, used to qualify almost all the offences. It is an indisputable fact that those adjectives and adverbs are subject of proof beyond reasonable doubt. They are equally open to judicial examination in spite of their subjective form. They constitute the question of fact to be tried on evidence. That being the case the words such as lawful justification, reasonable excuse, lack of willfulness, lack of guilty knowledge constitute defences open to tax defaulter/accused.

\section{Tax Clearance Certificate Requirement:-}

The failure of conventional enforcement measure in dealing with tax evasion is said to be the reason for recourse to tax clearance certificate system as a measure for income tax enforcement ${ }^{41}$. Notwithstanding, it is an effective enforcement instrument ${ }^{42}$. Tax clearance certificates are official written assurances by the relevant tax authorities evidencing that the tax payer has fulfilled his civic responsibility for the three years immediately preceding the current year of assessment. In other words, they are certificates issued by the relevant tax authority to the effect that the company or the individual stated thereon has paid all taxes assessed on it up to a particular period or that it is not liable to $\operatorname{tax}^{43}$.

The certificates must particularly disclose chargeable income; tax payable; tax paid, tax outstanding or alternatively a statement to the effect that no tax is due; source of taxpayer's income and purpose for which tax clearance certificate is sought ${ }^{\mathbf{4 4}}$.The rationale for tax clearance certificate is not far to seek. Every citizen has some legal rights which entitle him to a just and valid claim from the government, its agencies or an individual ${ }^{\mathbf{4 5}}$. Also, citizens have legal duties to perform to the government that renders a person liable to coercion or punishment for neglecting it. One of such is tax obligation of every tax payer. A person who benefits from the society must establish that he is a good citizen. One of the ways of showing this is the payment of tax as and when due ${ }^{\mathbf{4 6}}$. Tax clearance is therefore evidence that a person has performed his tax responsibility. It is a demonstration of reciprocatory obligation to the government.

Tiley J.- Revenue Law, Butherworths, London, 1978, p52

Abdulrazaq M.T. op.cit Pp21-22;

Nigerian Tax Reform in 2003 and Beyond op.cit p102

Adedokun K.A. op.cit p8

Section 101, CITA, 2004; section 85 (1) PITA, 2004

Section 101 (3) CITA, Section 85 (3) PITA

Section 33-46, CFRN, 1999

Afe Babalola-Election Law and Practice, Intec printers Ltd, Ibadan, 2007; p457 
Again, tax clearance certificates are necessary for those who wish to remit dividends, fees abroad since exchange control permission will not be granted to remit if an application is not supported with a tax clearance certificate. Foreigners leaving the country permanently usually require a certificate to enable them remit the balance of their funds in Nigeria ${ }^{47}$.From the foregoing, tax administrators usually issue two types of certificates- exemption certificate issued where there is an absence of liability; and exit certificate in the event of liability indicating that all taxes have been paid ${ }^{48}$.

The production of the tax clearance certificate is now a legal requirement both for individuals and companies as prerequisite for various economic and other purposes ${ }^{49}$. To satisfy the requirement of the law in all the transactions, the relevant tax authority is empowered to issue tax clearance certificate to a tax payer within two weeks of demand by him. The issuance must be preceded by assurance that such a person has paid tax or is not liable at all to tax for the three years immediately preceding the current year of assessment ${ }^{\mathbf{5 0}}$.It is worthy of mention that this enforcement instrument cannot be effective and the tax authorities alone cannot actualize the motive behind it. The maximum cooperation of other government ministries and parastatals is highly required more so that all the Government agencies are working towards actualizing the goals and objectives of the government concerned, and the government cannot function effectively well without stable revenue. The idea of penalizing any government ministry that fails to enforce this rule is commendable. ${ }^{51}$

One particular area that caught the attention of the writer of this paper is the area of public appointment and elective positions. The legislative houses are under obligation to ensure genuine tax clearance certificates are produced before any proposed appointments to either Federal or State Ministries are approved ${ }^{\mathbf{5 2}}$. Not only this, before any prospective candidate is elected into a public office at whatever tier of government, tax clearance is one of the required documents for such a candidate to scale through the hurdle of eligibility ${ }^{\mathbf{5 3}}$. Therefore both Independent National Electoral Commission (INEC) and States Electoral Commissions must cooperate with the relevant authority to ensure compliance with this law. However, there are divergent views of the Court of Appeal on whose duty it is to verify payment of tax as and when due in election matters. At one breath, some hold the view that it is the INEC and not Election Tribunal that should verify into the compliance of payment of tax as and when due by producing tax clearance certificate to evidence same ${ }^{\mathbf{5 4}}$.In other words, if the INEC is satisfied at the stage of screening that a candidate has paid the requisite tax for the prescribed period, a petition seeking the nullification of such candidate's election on the ground that he did not pay his tax as and when due is incompetent ${ }^{\mathbf{5 5}}$.In another $^{2}$ breath, others hold the view that election petition may be nullified on the ground of non-payment of tax as and when due even at election tribunal. ${ }^{\mathbf{5 6}}$

This shows that the court in some instances has passed the buck to INEC. But INEC, in a manner depicting how Nigeria government and its agencies are holding very important issue of revenue generation with a levity hand, in turn dodged the responsibility. INEC claims that candidates for elections into public offices are not by virtue of the relevant provisions of the 1999 Constitution, required to present a current tax clearance certificate unlike the position in the past ${ }^{57}$ In the humble view of this writer, neither of these views is a correct notion of the law. The

$47 \quad$ Section 101 (5) CITA; Section 85 (5) PITA

$48 \quad$ See Toby R.A op.cit 121 for details

$49 \quad$ Section 101 (3), CITA\& section 85 (3) PITA

$50 \quad$ Ibid

51 By virtue of section 85 (9) PITA (as amended) in 2011, a person be it a government organization or corporate entity to whom section $85(2)$ applies who fails to comply with same is guilty of an offence and is liable on conviction to a fine of $\mathrm{N} 5,000,000.00$ or to imprisonment for 3 years or both fine and imprisonment.

$52 \quad$ Section 147 (2) CFRN, 1999 to be read together with sections 85 (2) PITA and 101(2) CITA

53 State Government (Basic Constitutional and Transitional Provisions ) Decree, 1998

$54 \quad$ Lanto $v$ Wowo (1999) 7 NWLR (Pt 610) p227

$55 \quad$ Ikuomolav Ige\&ors (1992) 4 NWLR (pt 236) $511 @ 523$

$56 \quad$ Gatawa v. Bakwai (1998) 5 NWLR (Pt 554) 471 
assertion by INEC constitutes sheer shirk in responsibility. The Constitution and Electoral Act cannot be read in isolation without recourse to other vital enactment that has bearing with issue.

Section 85 (2) PITA and 101 (2) CITA mandates Government agencies to demand tax clearance certificate from persons. Sub-section (4) of the Acts, particularly PITA, states that the provisions of sub-section (2) of this section (i.e. section 85) SHALL apply in relation to appointment or election into public office among others. ${ }^{\mathbf{5 8}}$ It is not in dispute that INEC is an agency of the Government. It is an organ established by law through which the Federal Government carries out its electoral functions. Paragraph F 15 of the Third Schedule to the 1999 Constitution saddled INEC with the responsibility of conducting elections into the offices of President, Governor, and membership of legislative houses and other omnibus functions.

A combined reading of the provisions of the two enactments above stated reveals that the use of the word SHALL in them implies a mandate on INEC. The Companies' Income Tax Act and Personal Income Tax Act are Acts of National Assembly and particularly PITA confers a mandate on INEC to demand for tax clearance certificate of any prospective candidate for an election into the offices above stated. Any shirk in this constitutional responsibility by INEC will amount to aiding and abetting tax evasion.

Apart from INEC, the court cannot in the view of the writer, declined jurisdiction to entertain an election petition that set non-payment of tax as and when due as its major ground. With the pervading corrupt practices in Nigeria, a candidate for an election may manouvre his way out of INEC search by presenting a spurious or fake tax clearance certificate, having tricked tax official to achieve tax clearance racketeering ${ }^{59}$. The court being an important organ of government cannot close its eyes to a petition that hinges on this kind of instance. It is the collective responsibility of all organs of the government to ensure citizens pay their taxes as and when due. It is therefore not out of place to state that our courts are in contemplation by provision of Section 85 (2), PITA as agency of government. But to make it clearer, there is the need for our electoral laws to make non -payment of tax as and when due a ground for nullification of election petition.

\title{
Search and Seizure:-
}

Both the Personal Income Tax Act and Companies' Income Tax Act vest the relevant tax authority with power to enter and conduct a search in respect of a trade, vocation, profession or business carried on in Nigeria by a person. ${ }^{\mathbf{6 0}}$ The said tax authority must be satisfied that there is a reasonable ground for suspecting that an offence involving any form of total or partial non-disclosure of information or any irregularity or an offence in connection with or in relation to tax has been committed ${ }^{\mathbf{6 1}}$. The subsection prescribes what the state of mind of tax authority must be in order to make it lawful for it to decide to seize a document. He must suspect based on reasonable ground that tax fraud has been committed. The decision-making power is conferred by the statue on the officer of the relevant tax authority. He is not required to give any reason for his decision and the public interest immunity provides justification for any refusal to do so ${ }^{62}$.

Coupled with satisfaction or reasonable grounds, the relevant tax authority must have formed the opinion that evidence of the offence or irregularity is to be found in the premises, the registered office or place of management of the trade, vocation, profession or business or in the residence of the principal officer, factor, agent or representative of the individual ${ }^{63}$. The opinion and satisfaction of the relevant tax authority is not just conceptualized in the whims

\author{
$58 \quad$ Section $85(4)(\mathrm{S})$, PITA, 2004 \\ 59 Bombshell: Wabara not pay tax between 1993-1996 FBIR exposes senate president; in Saturday Sun \\ edition of March, 19, $2005 \mathrm{p} 8$ \\ $60 \quad$ Section 53 (1), Personal Income Tax Act, (PITA) CAP p8 LFN 2004 \& Section 64, Companies' Income \\ Tax Act (CITA) CAP C21 LFN, 2004 \\ Ibid \\ IRC v Roostminster Ltd (1980) STC P 56 Per Lord Diplock
}

63 Section 53 (1) (b) PITA, Section 64(2) CITA

73 IRC $v$ Roostminster (Supra) Per Lord Wilberforce 
and caprices of the tax officer. The investigation and intelligence section of the relevant tax authority must bring to bear its honest and investigative skills and wiles to entrap the person concerned. In other words, the tax officer must have the fore knowledge of prima facie credible information regarding evasion of tax by the assessee. This can be achieved if the relevant tax authority mounts secret surveillance on the business activities of the assessee.

The relevant tax authority may authorize any of its officers to enter, if necessary by force, the premises or place of management or residence of the said person at any time from the date of authorization to conduct the search. ${ }^{\mathbf{7 3}}$ The phrase "at any time" does not suggest a blanket opportunity for the tax officer to conduct the search at odd times. The authority to enter and conduct search must be in the form contained in the precedent of the warrant in the eighth schedule of the Personal Income Tax Act and sixth schedule of the Companies' Income Tax Act. In that regard therefore, the search must be in the daytime.

The authority given to tax officials to enter premises to conduct a search shall be carried out with warrant as an authority to enter issued by Federal Inland Revenue Service or State Internal Revenue. The word 'warrant' simply means a document issued by a person in authority under power conferred in that behalf authorizing the doing of an act which would otherwise be illegal ${ }^{65}$. The person affected has the right to be satisfied that the power to issue it exists. It therefore means the warrant should contain a reference to that power ${ }^{\mathbf{6 6}}$.

Having being armed with the warrant, the tax officer can search, seize and remove any records, documents and anything whatsoever found therein ${ }^{67}$. He should bear in mind while on this tax drive that he's not on a mission to distrain, as the person under this section is not in default of payment of tax yet. Therefore, anything whatsoever found in the premises envisaged by the Acts are in ejusdem generis with records, files, documents, computer system or any other information storage system which the tax officer has reasonable cause to believe may be required for the purposes of arriving at a fair and correct tax chargeable on the person or as evidence for the purposes of a proceedings in respect of offences of non-disclosure of relevant information to the tax authority ${ }^{\mathbf{6 8}}$.

The principles applicable to issue of search warrants under the criminal procedure code equally applied to searches and seizures made under tax laws. ${ }^{69}$ From the content of the precedent of warrant and authority to enter premises in $8^{\text {th }}$ schedule of Act, the warrant has no prescribed life span. In other words its validity is not affected, if not executed within the month or year of issue. It is equally not invalid only for non-indication of the nature of the things, which might be seized and removed. In other words it is not necessary that the warrant should specify particular books of account or document to be seized. A blank authorization to search and seize any papers that may be found is not bad in law. ${ }^{70}$ It cannot be expected that at the stage of search, there must be conclusive proof of the relevancy or usefulness of the materials seized. ${ }^{71}$ All that is necessary is that the tax officer must act honestly and believe, as reasonable persons, that the material would be relevant or useful. It may be that in a particular case, having regard to the magnitude of suspected evasion, a large quantity of material may have to be seized; that by itself does not make the search mala-fide. ${ }^{72}$

After the relevant tax officer, applying his mind and giving serious thought and consideration, issues a warrant of search and seizure, can it be said that the act violates the assesses fundamental human right to privacy? ${ }^{73}$ Can it also

See the Indian Case of SW Venkateswara Lodge v Comm. of Income Tax (1969) ITC VOl. 71 p.2. Note that Indian Tax System is similar in every respect with Nigerian Tax System

$70 \quad$ See the case of Durga Prasad v. HR Gomes (1966) AIR SC 1209

71 IRC $v$ Roostminster (Supra)

72 IRC v. Roostminster (1980)

73 Section 37, CFRN, 1999

STC p42 
be said to have expropriated the assessee's property thereby infringes his right to own immovable property? ${ }^{74}$ There are different views on this issue. First is the fact that though the integrity and privacy of man's house and of his place of business are important human right. However, the right may be eroded by a number of statutes passed by the parliament in the belief presumably that this right of privacy ought in some cases to be overridden by the interest, which the public has in preventing evasion of the tax law. Second, to issue search warrants which are based on no more than suspicion is an unnecessary power, which dangerously encroaches on person's liberty. It can lead to disastrous results for persons who may be innocent of fraud. ${ }^{75}$ Nevertheless, a tax officer will be justified if a positive law empowers him to enter into tax payers' business premises to conduct a search. ${ }^{76}$ Although the provision of tax law regarding search and seizure is restrictive and derogatory from the assessee's fundamental right to privacy and ownproperty, however, the restriction and derogation are justifiable by virtue of Section 45 of the 1999 Constitution of Nigeria. All that the tax officer need to bear in mind while acting under the warrant of search and seizure is that he should not be arbitrary, indiscriminate and highhanded.

\section{Institutional Mechanisms:- \\ Federal Inland Revenue Service:-}

For a tax system to be effective and efficient, it is necessary to create statutory authorities which perform both technical and management functions in the administration of the tax law. Otherwise, a good tax policy may end up looking remarkably alike in the hands of incompetent administration. These administrative agencies are equally creation of statutes. At the Federal level, the Federal Inland Revenue Service and the Joint Tax Board are the administrative machineries for enforcement of income tax.

As regards the administration of the personal income tax, tax authority includes the Federal Inland Revenue Service. The service administers personal income tax on persons employed in the Nigerian army, the Nigerian Navy, the Nigerian Air Force, the Nigerian Police Force other than in a civilian capacity, the officers of the Nigerian Foreign Service, every resident of the Federal Capital Territory Abuja and a person resident outside Nigeria who derives income or profit from Nigeria. ${ }^{87}$ It equally administers companies' income tax among others. The service, as it is presently constituted is established by the Federal Inland Revenue Service (Establishment) Act 2007, as a body corporate which can sue and be sued in its own name, with perpetual succession and a common seal and may hold, acquire and dispose of any property or interest in property, movable or immovable. ${ }^{88}$

It is informative to note that the FIRS as it is constituted has some unique features which make it more democratically inclined than as it was before 2007. In the first instance the FIRS is now an autonomous entity and it is recognized as an arresting and prosecuting authority on tax related matters. ${ }^{89}$ Though, this is a progressive stance that will require secondment of officers from the investigation department of FIRS to the Nigeria Police Force for acquisition of basic investigative skills, it is doubtful if this is achievable as there is zero or limited skills in the investigation of crimes by the police itself. ${ }^{90}$ Remarkably, the new service is inhered with democratic prospects. Its objective is to control and administer inter-alia, Personal Income Tax Act, Companies' Income Tax Act etc, as well as subsidiary legislations thereto; with the mandate to account for the tax collected in such a manner that the citizenry shall have a sense of fulfillment in having participated in paying their taxes honestly and promptly. This is a manifestation of having made positive and useful contribution to the advancement, progress and well-being of their various communities.

$\begin{array}{ll}74 & \text { Ibid, Section } 44 \\ 75 & \text { IRC v. Roostminster (Supra), Per Lord Wilberforce } \\ 76 & \text { Latick v Carrington (1764) 19 State tr. } 1029 \text { @ } 1066 \text { Per Lord Camdem }\end{array}$

78 Section 1 (2) (a-c), FIRS (Establishment) Act, 2007

79 Section 8, FIRS Act, 2007

$90 \quad$ Improve Your Basic Skills, NBA tells Police in Daily Trust, Friday, September 3, 2010

$91 \quad$ Section 8 (n), FIRS (Establishment) Act, 2007 
In all, the FIRS is saddled among others with the responsibilities of apprehending tax fraudsters and evaders, investigating and prosecuting tax defaulters, maintaining adequate data bank on taxation, network with complimentary agencies, organizing enlightenment programs and undertaking Research. ${ }^{\mathbf{1}}$

One of the outcomes of the Nigerian tax reform in 2003 is the conceptualization of the idea of having a one-stop point for the taxpayer to meet all tax needs. To make this happen, a new organizational structure was introduced. It is known as integrated tax office. The concept of the Integrated Tax Office is such that whereas the area Tax Offices were handling income tax matters and VAT offices handling VAT matters, all tax matters are now to be handled within one tax office. ${ }^{92}$

The service has as its principal functions, the power and duty to assess, collect, account for and enforce payment of companies' income tax and personal income tax among others. However, by paragraph 7, part 2 of the second schedule to the 1999 constitution collection of personal income tax particularly is on the concurrent legislative list. That being the case, the National Assembly may make law prescribing how the tax will be collected by the state; and as the National Assembly has made the law in this regard which is PITA 1993 one wonders whether the same National Assembly can make another law (i.e. FIRS Act 2007) on the collection of the same personal income tax. Furthermore, by virtue of section 8 of the FIRS (Establishment) Act 2007 the functions of the FIRS are expanded. This consequently will call for enlargement of the work force in the institution otherwise the carrying out of the functions will be counter-productive. The expected performance from the staff members will not be realized as they would have chewed more than they can swallow.

\title{
The Joint Tax Board:-
}

The Joint Tax Board, as it is today is a creation of the Personal Income Tax Act $1993 .^{\mathbf{9 3}}$ Its establishment is a good attempt at coordinating the types and nature of taxations allowable within the peculiar circumstances of each unit of the federation. ${ }^{94}$ It is in furtherance of the federal nature of the 1999 constitution that all taxes chargeable be channeled through the Joint Tax Board. ${ }^{95}$ It is one umbrella body under which tax matters are being simplified and harmonized.

One queer power given to JTB is the power to impose its decisions on matters of procedure and interpretation of tax Acts on any state for purposes of conforming to agreed procedure or interpretation.96 The idea of imposition without consideration of the benefit of the decision to be imposed on the state is in the humble view of this writer at variance with democratic virtue.

\section{The Court:-}

Enforcement of tax is a long chain which sometimes is completed by the judiciary. This makes it imperative that whatever emanate from the court should be in consonant with fairness and justice. The handling of tax related cases is crucial as it is expected to normalize anomalies in the process. The grouse of most people is that court hardly assist effective taxation in Nigeria because of interminable delays in court process; lack of tax expertise on the part of most judges existing congestion of courts with non-tax cases; widespread ambiguities in Nigeria tax cases and host of others. ${ }^{97}$

It will therefore assist enforcement of income tax if a tax division of the regular High Court system in Nigeria should be established to handle tax cases by High Court Judges with expertise in tax matters. If this is impossible, it is suggested that while deciding on a tax matter amicus curiae may be invited by the courts. This will enrich and enhance tax law jurisprudence. In addition to this, it is desirable that the court rules are adjusted to ensure that tax cases (because of their revenue nature) are completed within limited time possible.

\section{Conclusion:-}

\author{
Ibid, Section 8 (r) \\ Section 86 (1), Personal Income Tax Act, (PITA), CAP P8, LFN, 2004 \\ See the Case of Eti-Osa Local Government v Jegede (2007) 10 NWLR (Pt 1043) p537 @ 558-559 \\ Ibid \\ Section 86 (9) (a-e), PITA, 2004 \\ Nigerian Tax Reform, in 2003 and Beyond op.cit p108
}


From the foregoing analysis, the paper finds that there are unnecessary duplications of provisions of taxing statute which tends to create confusion in compliance and understanding. Not only this, it is discovered that some tax administrators exhibit ignorance of the basic enforcement provisions and this engenders misapplication of the laws guiding enforcement. Furthermore, some provisions of income tax laws relating to enforcement are not only harsh and inquisitorial but also not in consonance with constitutionalism. The effect of this is the creation of hostile relationship between the tax payers and tax administrators. To avoid this, tax mobilization provided for in the Federal Inland Revenue Service(Establishment)Act should be utilized maximally as an addition to the existing legal instruments for the income tax enforcement in Nigeria. This may appeal more to the conscience of tax payers for ultimate compliance by their internal self -will. Finally, there is the need for designating division of regular High Court to entertain tax matters to enhance quick disposition of tax cases particularly in some states that have not done so.

In conclusion, enforcement is the hall mark of a good tax system. It can only be vibrant if the legal mechanisms are proactive and the proceeds realized from tax payment are judiciously used for the benefit of the citizens. The tax payers and other stakeholders have vital roles to play in this regard. A tax payer having paid his taxes promptly is under additional civil obligation of being vigilant to ensure that the tax proceeds are judiciously utilized in a manner to secure the maximum welfare and enjoyment of their rights as enshrined in the Constitution. ${ }^{98}$

98 Adedokun K. A - Taxation and Fundamental Human Right Issues in Nigeria, An Article Published in Ahmadu Bello University Journal of Commercial Law (ABUJCL), vol. 4, No1, 2008-2009 